\title{
Analisis Kesadahan Air Alkali Yang Beredar Di Kota Mataram Nusa Tenggara Barat
}

\author{
Lale Budi Kusuma Dewi ${ }^{1}$, Ida Bagus Rai Wiadnya ${ }^{2}$, Iswari Pauzi ${ }^{3}$ \\ 1-3 Jurusan Analis Kesehatan, Poltekkes Kemenkes Mataram, Indonesia
}

\begin{tabular}{l} 
Article Info \\
\hline Article history: \\
Received Jul 01 $1^{\text {th }}, 2019$ \\
Revised Jul $11^{\text {th }}, 2019$ \\
Accepted Aug 01 $01^{\text {th }}, 2019$ \\
\hline
\end{tabular}

Keyword:

Hardness

Alkaline water

\begin{abstract}
Alkaline water refers to electrolyzed water produced from minerals such as magnesium and calcium, which are characterized by hydrogen saturated, high $\mathrm{pH}$, and negative oxidation reduction potential. Water that contains a lot of calcium and magnesium ions is called hard water. Magnesium hardness in drinking water is $500 \mathrm{mg} /$ liters, while the $\mathrm{pH}$ requirement for drinking water is 6.5 to 8.5. This study aims to analyze the safety of circulating alkaline water in Mataram City based on hardness levels. This study aims to analyze the safety of circulating alkaline water in Mataram City based on hardness levels. about 30 alkaline water samples with ph labels 9,10 and 11 respectively 10 samples were analyzed for hardness levels. The average levels of alkaline water hardness with ph label 9, 10 and 11 are $99 \mathrm{mg} /$ liters, $118 \mathrm{mg} /$ liters and $117 \mathrm{mg} /$ liters, respectively. Based on the hardness level, the alkaline water circulating is still suitable for consumption.
\end{abstract}

\begin{abstract}
ABSTRAK
Air alkali mengacu pada air elektrolisis yang dihasilkan dari mineral seperti magnesium dan kalsium, yang ditandai dengan hidrogen jenuh, $\mathrm{pH}$ tinggi, dan potensial reduksi oksidasi negatif. Air yang banyak mengandung ion kalsium dan magnesium disebut air sadah. Kadar maksimum kesadahan dalam air minum adalah $500 \mathrm{mg} / \mathrm{liter}$, sedangkan persyaratan pH air minum adalah 6,5 sampai 8,5. Penelitian ini bertujuan untuk menganalisa keamanan air alkali yang beredar di Kota Mataram berdasarkan kadar kesadahan. Terhadap 30 sampel air alkali dengan pH label 9, 10 dan 11 masing-masing sebanyak 10 sampel dilakukan analisa kadar kesadahan. Rata-rata kadar kesadahan air alkali dengan pH label 9, 10 dan 11 berturut-turut adalah $99 \mathrm{mg} / \mathrm{liter}, 118 \mathrm{mg} / \mathrm{liter}$ dan $117 \mathrm{mg} / \mathrm{liter}$. Berdasarkan kadar kesadahan, air alkali yang beredar di Kota Mataram masih layak konsumsi.
\end{abstract}

Kata Kunci : Kesadahan, Air Alkali

Copyright $\odot$ Jurnal Analis Medika Bio Sains

\section{Pendahuluan}

Kemajuan sosial ekonomi dan perkembangan informasi saat ini menyebabkan perubahan gaya hidup dan pola konsumsi masyarakat ke arah yang lebih praktis dan efisien, salah satunya adalah konsumsi air minum dalam kemasan. Dalam beberapa tahun terakhir, berbagai jenis air minum dalam kemasan, tidak hanya untuk menghilangkan dahaga tetapi juga untuk menjaga kesehatan (Sumarna, 2006). Beberapa tahun terakhir banyak beredar produk air alkali yang dipromosikan sebagai air sehat. Air alkali dapat diminum dan direkomendasikan dalam literatur komersial dan pemasaran karena bermanfaat dalam pengobatan masalah pencernaan, hipertensi, diabetes dan kanker (Henry \& Chambron, 2013), memiliki efek anti obesitas (Mistica et al., 2013), memiliki manfaat terapeutik untuk pasien dengan penyakit refluks (Koufman \& Johnston, 2012) dan laporan Ara et al., 2017 menunjukkan air alkali dapat memperbaiki ketidakseimbangan patofisiologis (hormonal, metabolik, dan imunologis) yang ditimbulkan oleh PCOS (Polycystic ovarian syndrome), sehingga meningkatkan infertilitas pasien PCOS. 
Peralatan yang elektrolisis air minum untuk keperluan rumah tangga telah tersedia selama beberapa tahun. Mesin elektrolisis ini menghasilkan air asam dan air alkali (Henry \& Chambron, 2013). Air alkali mengacu pada air elektrolisis yang dihasilkan dari mineral seperti magnesium dan kalsium, yang ditandai dengan hidrogen jenuh, pH tinggi, dan potensial reduksi oksidasi negatif (Mistica et al., 2013).

Alkalinitas suatu larutan dapat diukur berdasarkan nilai pH larutan. Nilai pH air murni adalah 7 dan nilai pH air bersih berkisar antara 6-8 (Soemardjo, 2009). Air yang banyak mengandung ion kalsium dan magnesium disebut air sadah. Dalam Peraturan Kementerian Kesehatan Republik Indonesia tahun 2010, No 492/Menkes/Per/IV/2010 persyaratan $\mathrm{pH}$ untuk air minum adalah $6.5 \mathrm{~s}$ ampai 8.5 sedangkan kadar maksimum kesadahan dalam air minum adalah $500 \mathrm{mg} / \mathrm{liter}$.

Di Jepang, air yang diionisasi telah menjadi industri yang penting dan terus berkembang. Sejumlah produsen telah $\mathrm{b}$ ergabung bersama membentuk sebuah organisasi yang disebut the Association of Alkaline Ionized Water Apparatus. Kementerian Kesehatan Jepang, mendukung asosiasi ini, tetapi juga meminta jaminan mengenai keamanan dan kualitas air yang dihasilkan oleh alat elektrolisis air.

Air alkali yang diproduksi oleh produsen air alkali di Kota Mataram memiliki kisaran pH 8 sampai 11. Harga air alkali lebih mahal dari air minum dalam kemasan (AMDK). Kisaran harga air alkali antara Rp. 9.000,- sampai Rp. 85.000,- tergantung pH air. Harga air alkali semakin mahal dengan semakin tingginya $\mathrm{pH}$. Masyarakat bersedia membeli air alkali dengan harga mahal untuk mendapatkan keuntungan berupa kesehatan yang dijanjikan oleh produsen air alkali.

Tujuan penelitian ini adalah untuk mengetahui bagaimana kualitas air alkali berdasarkan kadar kesadahan dalam air alkali.

\section{Metode Penelitian}

Penelitian ini merupakan penelitian observasi dengan desain cross sectional. Digunakan sampel sebanyak 30 sampel dibagi menjadi 3 kelompok yaitu sampel air alkali pH 9, pH 10 dan pH 11. Metode sampling non random porpusive sampling, dengan kriteria sampel adalah air alkali dengan pH 9, 10 dan 11.

Analisa kadar kesadahan air alkali dengan metode titrasi kompleksometri dilakukan dengan prosedur dipipet 50,0 $\mathrm{ml}$ sampel air alkali dan dimasukkan ke dalam labu erlenmeyer. Ditambahkan dengan buffer $\mathrm{pH}$ 10 dan ditambahkan dengan indikator EBT. Selanjutnya dititrasi dengan menggunakan larutan Natrium EDTA 0,05 M sampai titik akhir titrasi yang ditandai dengan perubahan warna larutan dari merah anggur menjadi biru terang. Dicatat volume titrasi dan dihitung kadar kesadahan air alkali.

\section{Hasil Penelitian dan Pembahasan}

Sampel untuk penelitian ini diambil dari produsen air alkali di Kota Mataram. Pada saat penelitian ini dilakukan, produsen sudah tidak memproduksi air alkali dengan pH 11 dan mengakui air dengan pH 11 sudah tidak layak konsumsi. Untuk kepentingan penelitian ini, produsen bersedia membuatkan air alkali dengan $\mathrm{pH}$ 9, 10 dan 11. pH sebenarnya sampel air alkali diukur dengan menggunakan kertas $\mathrm{pH}$ universal. Hasil pengukuran $\mathrm{pH}$ air alkali yang sebenarnya dan kadar kesadahan air alkali dipaparkan pada tabel 1 sampai tabel 3.

\begin{tabular}{|c|c|c|c|}
\hline Kode & $\mathrm{pH}$ & $\mathrm{pH}$ & Kadar \\
\hline sampel & Label & Sebenarnya & $\begin{array}{l}\text { Kesadahan } \\
\text { Total }\end{array}$ \\
\hline 9.1 & 9 & 8 & $99 \mathrm{mg} / \mathrm{liter}$ \\
\hline 9.2 & 9 & 8 & $89 \mathrm{mg} /$ liter \\
\hline 9.3 & 9 & 8 & $109 \mathrm{mg} /$ liter \\
\hline 9.4 & 9 & 8 & $109 \mathrm{mg} /$ liter \\
\hline 9.5 & 9 & 8 & $89 \mathrm{mg} /$ liter \\
\hline 9.6 & 9 & 8 & $99 \mathrm{mg} / \mathrm{liter}$ \\
\hline 9.7 & 9 & 8 & $99 \mathrm{mg} / \mathrm{liter}$ \\
\hline 9.8 & 9 & 8 & $89 \mathrm{mg} /$ liter \\
\hline 9.9 & 9 & 8 & $109 \mathrm{mg} /$ liter \\
\hline 9.10 & 9 & 8 & $99 \mathrm{mg} / \mathrm{liter}$ \\
\hline Rata-rata & & & $99 \mathrm{mg} / \mathrm{liter}$ \\
\hline
\end{tabular}


Tabel 2 Hasil pengukuran pH dan kadar kesadahan di dalam sampel air alkali label pH 10

\begin{tabular}{llll}
\hline $\begin{array}{l}\text { Kode } \\
\text { sampel }\end{array}$ & $\begin{array}{l}\mathrm{pH} \\
\text { Label }\end{array}$ & $\begin{array}{l}\mathrm{pH} \\
\text { Sebenarnya }\end{array}$ & $\begin{array}{l}\text { Kadar } \\
\text { Kesadahan } \\
\text { Total }\end{array}$ \\
\hline 10.1 & 10 & 9 & $109 \mathrm{mg} / \mathrm{liter}$ \\
\hline 10.2 & 10 & 9 & $119 \mathrm{mg} / \mathrm{liter}$ \\
\hline 10.3 & 10 & 9 & $119 \mathrm{mg} / \mathrm{liter}$ \\
\hline 10.4 & 10 & 9 & $129 \mathrm{mg} / \mathrm{liter}$ \\
\hline 10.5 & 10 & 9 & $109 \mathrm{mg} / \mathrm{liter}$ \\
\hline 10.6 & 10 & 9 & $129 \mathrm{mg} / \mathrm{liter}$ \\
\hline 10.7 & 10 & 9 & $109 \mathrm{mg} / \mathrm{liter}$ \\
\hline 10.8 & 10 & 9 & $119 \mathrm{mg} / \mathrm{liter}$ \\
\hline 10.9 & 10 & 9 & $109 \mathrm{mg} / \mathrm{liter}$ \\
\hline 10.10 & 10 & 9 & $129 \mathrm{mg} / \mathrm{liter}$ \\
\hline Rata-rata & & & $118 \mathrm{mg} / \mathrm{liter}$ \\
\hline
\end{tabular}

Tabel 3 Hasil pengukuran pH dan kadar kesadahan di dalam sampel air alkali label pH 11

\begin{tabular}{llll}
\hline $\begin{array}{l}\text { Kode } \\
\text { sampel }\end{array}$ & $\begin{array}{l}\mathrm{pH} \\
\text { Label }\end{array}$ & $\begin{array}{l}\mathrm{pH} \\
\text { Sebenarnya }\end{array}$ & $\begin{array}{l}\text { Kadar } \\
\text { Kesadahan } \\
\text { Total }\end{array}$ \\
\hline 11.1 & 11 & 9 & $109 \mathrm{mg} / \mathrm{liter}$ \\
\hline 11.2 & 11 & 9 & $119 \mathrm{mg} / \mathrm{liter}$ \\
\hline 11.3 & 11 & 9 & $109 \mathrm{mg} / \mathrm{liter}$ \\
\hline 11.4 & 11 & 9 & $119 \mathrm{mg} / \mathrm{liter}$ \\
\hline 11.5 & 11 & 9 & $109 \mathrm{mg} / \mathrm{liter}$ \\
\hline 11.6 & 11 & 9 & $129 \mathrm{mg} /$ liter \\
\hline 11.7 & 11 & 9 & $129 \mathrm{mg} /$ liter \\
\hline 11.8 & 11 & 9 & $119 \mathrm{mg} / \mathrm{liter}$ \\
\hline 11.9 & 11 & 9 & $119 \mathrm{mg} / \mathrm{liter}$ \\
\hline 11.10 & 11 & 9 & $109 \mathrm{mg} / \mathrm{liter}$ \\
\hline Rata-rata & & & $117 \mathrm{mg} / \mathrm{liter}$ \\
\hline
\end{tabular}

Air alkali yang beredar di Kota Mataram tidak sesuai dengan $\mathrm{pH}$ pada label, dimana pada label tertera pH 9 menunjukkan hasil pengukuran $\mathrm{pH}$ 8, sedangkan pada air alkali pH label 10 dan 11 menunjukkan pH sebenarnya hasil pengukuran adalah rata-rata 9. Pengukuran $\mathrm{pH}$ dalam penelitian ini menggunakan kertas $\mathrm{pH}$ universal yang memiliki ketelitian pengukuran $\mathrm{pH}$ pada skala 1, sehingga angka desimal tidak dapat ditampilkan. Menurut Permenkes No. 492/Menkes/Per/IV/2010, pH air minum yang memenuhi persyaratan adalah 6,5 sampai 8,5.

Beberapa gangguan kesehatan mungkin diatasi dengan alkalinitas air alkali, tetapi konsekuensi merugikan jangka panjang konsumsi air alkali dengan $\mathrm{pH} 9$ sampai 11 atau setara dengan larutan natrium hidroksida pada $10^{-5}-10^{-3} \mathrm{~mol} /$ Liter secara teratur sebanyak 1-1,5 L/hari belum diteliti. Degradasi elektroda selama berfungsinya perangkat melepaskan partikel nano platinum yang sangat reaktif, toksisitasnya belum terbukti secara jelas sehingga direkomendasikan kepada otoritas kesehatan mengenai ketersediaan perangkat yang tidak terkontrol ini yang digunakan sebagai produk kesehatan, namun menghasilkan zat obat dan karenanya harus dijual sesuai dengan persyaratan peraturan (Henry \& Chambron, 2013)

Penggunaan air alkali dengan $\mathrm{pH}$ lebih dari 9 dilakukan oleh Permadani, Mardiyono, \& Santjaka tahun 2019. Air alkali dengan pH 9+ dikombinasi dengan senam secara efektif dan signifikan meningkatkan nilai laju aliran ekspirasi puncak pada hari ke 8 sehingga dapat diterapkan dalam manajemen asuhan keperawatan pada pasien dengan asma intermiten dan persisten.

Kadar kesadahan rata-rata air alkali pH 8 adalah 99 mg/liter dan kadar kesadahan rata-rata air alkali pH 9 adalah 117,5 mg/liter. Kadar kesadahan air alkali yang beredar di Kota Mataram memenuhi persyaratan menurut Permenkes No 492/Menkes/Per/IV/2010, dimana persyaratan kadar kesadahan maksimal adalah 500 $\mathrm{mg} /$ liter. 


\section{Kesimpulan}

Berdasarkan kadar kesadahan, air alkali yang beredar di Kota Mataram masih memenuhi persyaratan Permenkes No 492/Menkes/Per/IV/2010.

\section{Daftar Pustaka}

Ara, J., Nuwormegbe, S. A., Easter, M., Sajo, J., Shim, K., \& Lee, K. (2017). Potential therapeutic effect of alkaline reduced water in polycystic ovarian syndrome. Medical Hypotheses. https://doi.org/10.1016/j.mehy.2017.05.017

Henry, M., \& Chambron, J. (2013). Physico-Chemical, Biological and Therapeutic Characteristics of Electrolyzed Reduced Alkaline Water (ERAW). 2094-2115. https://doi.org/10.3390/w5042094

Kementerian Kesehatan Republik Indonesia. Persyaratan Kualitas Air Minum. , Pub. L. No. 492/Menkes/Per/IV/2010 (2010).

Koufman, J. A., \& Johnston, N. (2012). Potential benefits of pH 8.8 alkaline drinking water as an adjunct in the treatment of reflux disease. Annals of Otology, Rhinology and Laryngology, 121(7), 431-434. https://doi.org/10.1177/000348941212100702

Mistica, R., Ignacio, C., Kang, T., Kim, C., Kim, S., Yang, Y., ... Lee, K. (2013). Anti-obesity Effect of Alkaline Reduced Water in High Fat-Fed Obese Mice. Biol. Pharm. Bull., 36(7), 1052-1059.

Permadani, A. D., Mardiyono, M., \& Santjaka, A. (2019). The combination of alkaline water provision and asthma-induced gymnastics towards peak expiratory flow rate of asthma patients at Surakarta Lung Clinic, Indonesia. Global Health Management Journal, 3(1), 8-12. https://doi.org/10.1109/SKIMA.2017.8294127

Soemardjo, D. (2009). Pengantar Kimia Buku Panduan Kuliah Mahasiswa Kedokteran dan Program Strata I Fakultas Bioeksakta. Jakarta: EGC.

Sumarna, A. T. (2006). Analisis Preferensi Konsumen Air Minum Kemasan Beroksigen Merek AIROX (Studi Kasus Di Wilayah Kotamadya Bogor). Institut Pertanian Bogor. 